\title{
Diurnal behavioural differences in forager and nurse honey bees (Apis mellifera carnica Pollm)
}

\author{
K Crailsheim, N Hrassnigg, A Stabentheiner \\ Institut für Zoologie an der Karl-Franzens-Universität, Universitätsplatz 2, A-8010 Graz, Austria
}

(Received 23 March 1996; accepted 31 July 1996)

\begin{abstract}
Summary - Bees defined as nurses by age (7-12 days), or as foragers by behaviour, were observed for $1.5 \mathrm{~h}$ around noon during days with good weather conditions and during the following night around midnight. Nurse bees spent more than half of their time in the broodnest and their average periods of activity and inactivity were rather similar during day and night, except that the feeding of adults was more frequent during daytime. Foragers had a more cyclic lifestyle, spending most of their time outside the broodnest. During daytime they flew and had shorter periods of inactivity compared to nighttime and compared to nurse bees. Trophallactic interactions of foragers were much more frequent during daytime and they were more often fed than nurses. In contrast to nurses, we never saw foragers taking food from honey cells, and seldom visiting pollen cells. That foragers seldom eat honey and frequently receive food during daytime demonstrates the important role of passive trophallaxis for the foragers.
\end{abstract}

social behaviour / day and night / division of labour / trophallaxis

\section{INTRODUCTION}

Rösch (1925, 1930) and Lindauer (1952) provide detailed descriptions on the division of labour in honey bee colonies. The main task (eg, cleaning, nursing, food preparation, foraging) a bee performs at a specific period in its life depends on its age, the age demography of the bees in the colony, the actual demands of the colony and of course on the conditions outside the nest, such as season, weather and availability of food.

While nurses mainly perform tasks which are required throughout the day (24 h), foragers depend on more or less good weather conditions, light and temperatures above $10^{\circ} \mathrm{C}$ to perform their primary tasks, ie, the collecting of nectar, pollen, resin and water (Heinrich, 1979; Corbet et al, 1993). Circadian rhythms of foragers are documented by Frisch and Aschoff (1987), Moore et al (1989) and Moore and Rankin (1993). Lindauer (1952) showed that the proportion of work and rest in honey bee No 115, which he observed continuously in its first 8 days of life during which it already acted as a nurse, was almost the same during the day and the night. He also observed one forager bee for 2 days and nights. This bee did not work most of the time, but was patrolling and idle with some short flights during day. 
Kaiser (1988) described resting honey bees in an observation hive showing signs of sleep with a decreased body temperature and muscle tone, reduced motility, relative insensitivity to strong (visual) stimuli and a tendency to adopt a preferred resting posture and to rest at a preferred location in the hive. In the latest findings, the behaviour of pollen foragers was recorded in an observation hive at night by Sauer and Kaiser (1995); almost all pollen foragers were shown to rest at night.

The location of a bee inside the hive correlates with the tasks it performs (Seeley, 1982). Young bees stay mainly in the broodnest area where they nurse brood. Middle-aged bees perform food-handling tasks throughout the nest, and the oldest bees forage outside the nest.

We also wanted to test for differences in other aspects of behaviour. Free (1957) described various trophallactic interactions among bees of all age classes. Other authors (Crailsheim, 1991, 1992; Camazine, 1993) reported that there are specific interactions related to protein metabolism between the nurse and the forager task group. Dreischer (1956) considered that foragers might be provided with protein by younger bees and Crailsheim (1992) used radioactive tracer methods to prove that there is indeed a transfer of protein between the two task groups.

The goal of this study was to test for temporal variation (day and night) in the performance of the behaviour of workers in the nurse and forager task groups. Of special interest were the trophallactic interactions as a visible way of food transfer and communication.

\section{MATERIALS AND METHODS}

One colony in an observation hive with glass walls (von Frisch, 1965) and three vertically arranged frames $(22 \times 42 \mathrm{~cm})$ was used. There was an area of at least $250 \mathrm{~cm}^{2}$ of open brood and a worker population of approximately 5000 bees; there were always open and sealed honey stores and beebread in the colony. To have one area definitely free of brood, a queen excluder was fixed between the lowest and the middle comb. The size of the broodnest (open and sealed brood) was marked on the glass wail of the colony every day to facilitate the recording of the location of a bee (inside or outside the brood nest). In other experiments in the same observation hive we recorded temperatures of the broodnest from 33.5 to $34.5^{\circ} \mathrm{C}$ and temperatures in the lower comb from 21 to $28^{\circ} \mathrm{C}$.

During summer 1995 bees that had emerged in an incubator were number-coded and introduced into the observation hive. Bees were coded seven times. In total 78 workers were added to the colony, which should not have had an effect on the population dynamics of the colony or the caste ontogeny of the workers. We observed these bees between 7 and 12 days of age and defined them as nurses. Pollen foragers were coded upon returning from foraging and observed from the next day on. Observations were done on days with good foraging conditions (intense foraging activity of the colony during more than $50 \%$ of the daytime observation period) and the following nights only, from the end of July (26th) until the middle of August (16th) 1995. Bees were chosen randomly for observation from the group of marked bees that could be detected at the beginning of the observation period. Each bee was investigated by one observer with magnifying glasses and a flashlight (red during night) whenever necessary.

Each datapoint used for the statistics is the result of observing one bee for $90 \mathrm{~min}$ (ie, one observation period). Four bees were observed in parallel. Observations were made between 11:00 am and 3:00 pm as well as between $10: 00 \mathrm{pm}$ and 2:00 am. We used red light at night. The data from a bee were rejected when it could not be observed during more than $60 \%$ of the 90 $\mathrm{min}$. The duration of activities was calculated as a percentage of the period the bee could be located (the location during flight was called in flight'), frequencies as events per hour or per day. Every 5 min the location of the observed bee inside the hive was recorded to calculate its presence inside or outside the broodnest.

\section{Behavioural patterns}

These were classified as follows. 


\section{Absolutely inactive}

The bee stays in an empty cell without detectable movements of the abdomen or sits motionless with immobile antennae.

\section{Idle}

The bee sits and moves its antennae or legs or walks with a velocity of less than $5 \mathrm{~mm}$ per second (in no particular direction).

\section{Patrolling}

The bee walks across the comb at a rate of about 5-10 $\mathrm{mm}$ per second.

\section{Nursing brood}

The bee has its head inside a cell within the brood area for more than $5 \mathrm{~s}$ and its body moves; in most cases the presence of larvae was also checked afterwards.

\section{Trophallactic contacts (donating and receiving)}

One bee (recipient) puts its tongue between the mandibles of another one (donor) for more than $2 \mathrm{~s}$.

\section{Visiting pollen and honey cells ('eating pollen and honey')}

The worker inserts its head into a cell containing pollen or honey for more than $2 \mathrm{~s}$. We assume, without actual proof, that these bees are consuming honey or pollen. For each individual bee observed to eat pollen, the mean duration of visits to pollen cells was calculated. The mean duration of visits of all bees was then calculated from these data. Those observation periods in which bees never were seen to visit pollen cells were not taken into account for the calculation of mean duration. The procedure was the same for visiting honey cells.

The mean daily frequency of consumption was calculated by: (all observations (events) with bees inside pollen (honey) cells $\times 24 \mathrm{~h}$ ) / (duration of period all bees could be located).
For this estimation we counted all feedings within one observation period as one event.

\section{Wax manipulation}

Wax of brood caps or cells or on the frames was manipulated in any way.

\section{Other activities}

Other activities included various behaviours such as flight and dancing.

\section{Statistics}

The sample size comprised a minimum of 45 observation periods for nurses and foragers, respectively, during day and night. Data were tested by the Mann-Whitney $U$-test, as data could not be proven to be distributed normally. Means and standard deviation are given. The level of statistical significance was set at $P=$ 0.05 .

\section{RESULTS}

\section{Location}

Nurses were in the area of the broodnest for more than half of the time, independent of time of day (fig 1). They were very seldom seen in the non-brood area below the queen excluder (data not documented). Foragers spent most of the day outside the broodnest but were occasionally seen inside the broodnest, even though it was distant from the entrance of the hive. The rest of the time they were outside the hive (flying).

\section{Absolutely inactive}

There is a significant difference in this behaviour between foragers and nurses dur- 
ing day and night. While nurses were inactive for only a short period independent of time of day, foragers had long periods of inactivity during night and much fewer during the day (fig 2a).

\section{Idle}

In nurses as well as foragers, this behaviour was evenly distributed during day and night, though it was seen less often in the forager task group (fig 2b).

\section{Patrolling}

Foragers patrolled significantly more during the day than during the night. Nurses showed this behaviour to a significantly higher proportion than foragers, with no differences between day and night (fig 2c).

\section{Wax manipulation}

Nurses showed this behaviour during day and night, but foragers never did (fig 2d).

\section{Nursing brood}

Independent of time of day nursing by nurse bees lasted for $3 \%$ of the duration of the observation period. It was almost never observed in foragers (fig 2e).

\section{Trophallactic interactions}

There was a trend toward more trophallactic interactions during the day than during the night for nurses; this was even more pronounced for foragers. Nurses donated food more often during daytime than during nighttime, but they received food at an equal rate during day and night (fig 3a). Foragers donated food more often and were fed more often during daytime than during nighttime (fig $3 b$ ). Foragers received food more often than they donated food during nighttime. Though the data showed the same tendency for the daytime, this difference was not significant.

\section{Visiting pollen and honey cells}

Nurse bees often visited honey cells during the day and night, ie, in approximately $30 \%$

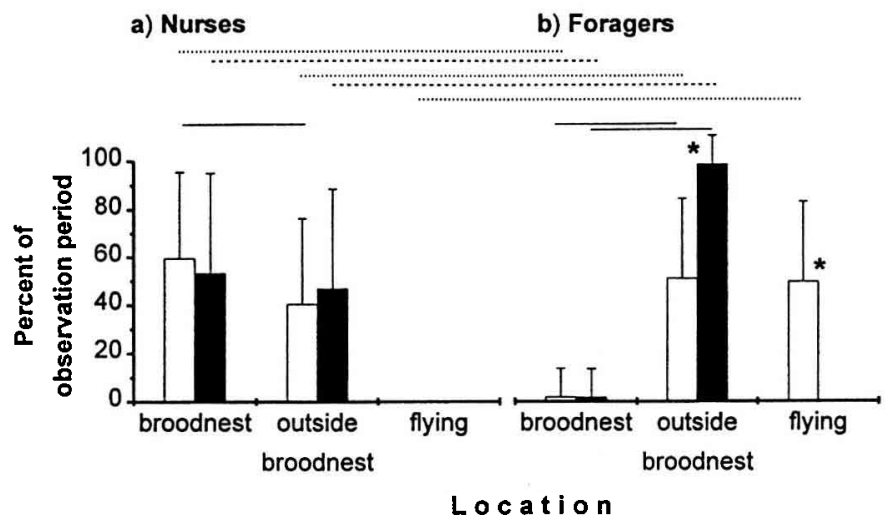

Fig 1. Location of nurses and foragers inside the hive in the broodnest area and outside the broodnest, and foraging outside the hive, during day and night (means \pm SD). The period a bee could be located was $100 \%$. Horizontal lines above columns indicate a significant difference; asterisks indicate a significant difference between day and night; $(P<0.05) ; \sqcup$ day; $\square$ night. 
a) Inactive

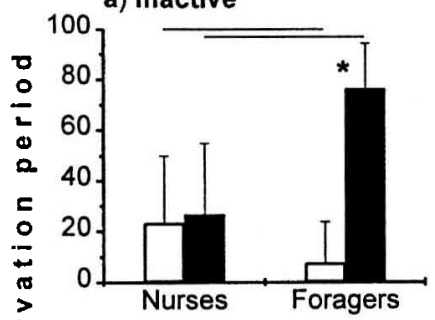

d) Wax manipulation

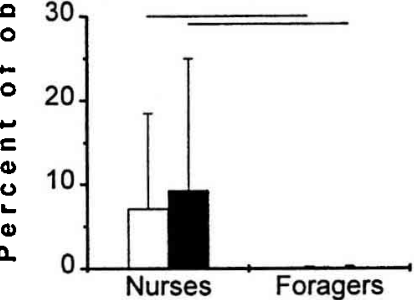

b) Idle

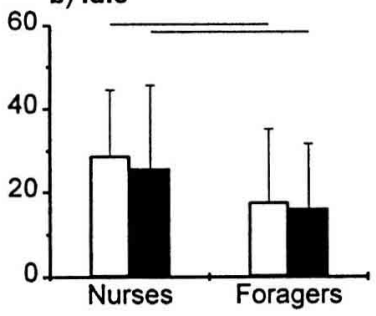

e) Nursing brood

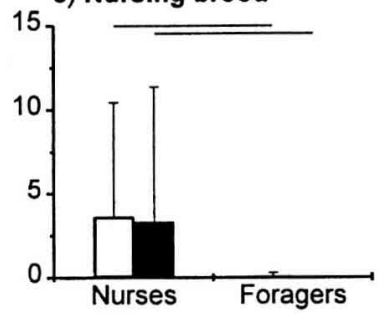

c) Patrolling
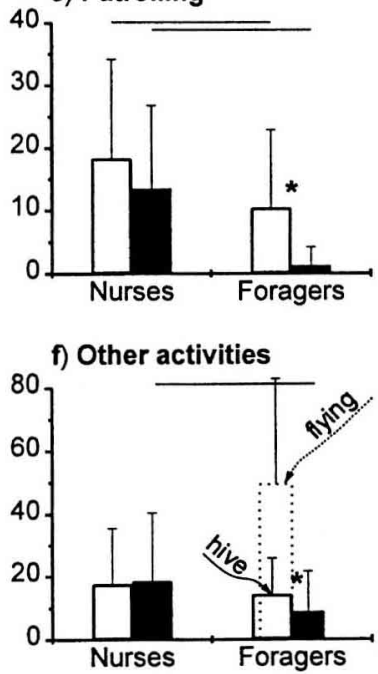

Fig 2. Percentage of the observed period spent for various activities during day and night (means $\pm S D$ ). In (f) (Other activities) foraging is separated from within-hive activities and is not considered in the statistics. The period a bee could be located was $100 \%$. Horizontal lines above columns indicate a significant difference between task groups at the same time of day; asterisks indicate a significant difference between day and night; $(P<0.05) ; \mid$ day; night.

of observed periods, but foragers were never seen in honey cells. Nurses or foragers were very seldom seen in pollen cells (fig $4 a$ ). The mean period covering visits to pollen and honey cells within the observation time of $1.5 \mathrm{~h}$ is given in fig $4 \mathrm{~b}$. The mean daily rate of consumption of pollen (at least of visiting a pollen cell, see discussion) was calculated as 1.25 times per day in nurses (mean dura- tion for visiting one cell, day and night summed up: $197 \pm 230 \mathrm{~s}, n=8$ ) and 0.87 times per day in foragers (mean duration: $113 \pm 53 \mathrm{~s}, n=5$ ). Nurses ate honey (or at least had their head in a honey cell) 4.5 times per day (mean duration for visiting one cell during day: $105 \pm 133 \mathrm{~s}, n=13$; during night: $93 \pm 96 \mathrm{~s}, n=16$ ), but foragers never did during the investigated periods. a) Nurses

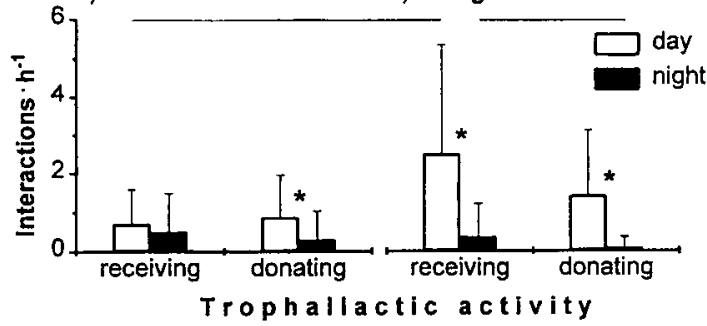

Fig 3. Number of trophallactic interactions (receiving and donating food calculated per hour) of nurses and foragers during day and night (means \pm SD). Horizontal lines above columns indicate a significant difference; asterisks indicate a significant difference between day and night $(P<0.05)$; $\square$ day; $\square$ night. 


\section{Other activities}

All other activities which are not listed separately are summarized in figure $2 \mathrm{f}$. Both day and night, nurses spent nearly $20 \%$ of the observation time upon activities other than those listed above. Foragers performed many flights during daytime which resulted in a significant difference in their activity pattern between day and night, but additionally foragers also showed a significant difference between day and night, when foraging was not considered. Comparing the 'other activities' statistically (day and night, foragers and nurses) calculations were restricted to in-hive duties only and foraging was excluded.

\section{DISCUSSION}

To detect differences in behaviour during day and night in foragers and nurse bees, observations were conducted around midday and midnight. These two situations are quite extreme. The restriction to good weather conditions was applied to eliminate the influence of varying weather conditions and food flow on behaviour.

Observed foragers were very inactive at night, staying mostly in the lower part of the hive and clinging to a quiet cluster of bees. On the other hand, foragers are more active than nurses during daytime, when they are performing flights. Foragers are less active at in-hive activities than nurse bees (see fig
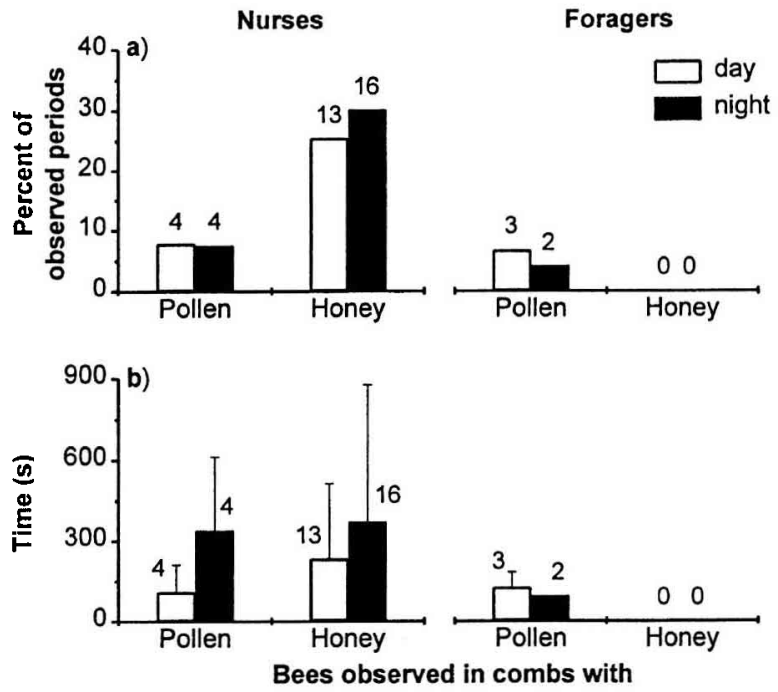

Fig 4. Nurse and forager bees observed in combs with pollen and honey. a) Proportion of observation periods in which visits to pollen and honey cells were observed, figures above columns indicate the absolute numbers of observation periods in which the specific task was performed. b) Mean period one bee was seen in cell with pollen or honey during one observation period (only bees that actually visited cells with pollen or honey were used for these calculations). Figures above columns indicate the absolute numbers of observation periods in which the specific task was performed. Given are means $\pm S D$. $\square$ day; $\square$ night. 
2). Nurses spent most of their time within the broodnest area, where they tend brood and move around, as reflected by the data on patrolling and idleness (fig 2). Nurses fed brood only during $3 \%$ of the investigated period but calculated for 1 day $(24 \mathrm{~h})$ this would be almost three quarters of an hour, a period that is quite long. Considerable time was also spent in the non-broodnest area, both day and night. Nurses had to leave the broodnest area at least to supply themselves with honey or pollen. In our experiments we restricted the broodnest to the upper two combs by means of a queen excluder screen. When the broodnest is closer to the entrance, foragers are probably more often within it.

It is quite difficult to judge what bees really do when being observed inside cells, for instance in many cases, when a worker bee disappears inside a cell we are only able to suppose what it is doing in there, eg, eating honey or pollen and nursing, if it stays inside a cell containing honey, pollen or brood. It was long presumed that all young worker bees that enter empty cells are cleaning these cells (Rösch, 1925; Lindauer, 1952) but the latest information on this specific behaviour shows that most of these bees are probably just resting (Blom, 1993).

With this in mind, we defined 'eating pollen' or 'eating honey' when the bee was seen with its head inside a cell containing pollen or honey, as though we cannot state with certainty what it really did inside the cell; pollen mashing was never observed in our two task groups. Although nurses were detected visiting a honey cell relatively often, foragers were never seen putting their head into a honey cell; we conclude that they never ate honey from cells during the observed period. As the total observation time was quite long (see Materials and methods) eating honey from cells is rather unlikely at this age and in a well-provided colony. Therefore, it seems quite obvious that foragers are supplied by trophallaxis, as is frequently seen in our experiment, and which is confirmed by observations during investigations of the thermal behaviour of dancing forager bees (Stabentheiner et al, 1995). Stabentheiner and coworkers also observed that waggle dancing bees, trained to a remote feeder, search actively for the 'proper' bee as a donor. Nonetheless we cannot exclude that foragers feed themselves on honey at other times of the day, for instance, in the morning before they start to forage.

When foragers perform flights around noon, they are fed significantly more often than at night, when they mainly stay motionless in the lower part of the colony. This latter 'activity' was described extensively by Kaiser (1988), Kaiser and Steiner-Kaiser (1988), Kaiser (1995), and Sauer and Kaiser (1995). At night when they do not forage they receive food by trophallaxis more often than they donate food themselves; there is a similar tendency also during the day. In our observation hive, in which we kept brood away from the lowest comb, foragers did not move into the broodnest area with the specific aim of finding a nurse bee and being supplied with jelly during the observed period (fig 1b). However, there are many opportunities for trophallactic interactions between nurses and foragers outside the broodnest as well, since nurses were seen there for $40-47 \%$ of the observation time (fig 1a). Watching trophallactic interactions we are able to assume a transfer of food, but are unable to distinguish between the transfer of carbohydrates and/or protein by visual observation. Moreover, although our lower threshold for defining a trophallactic contact was $2 \mathrm{~s}$, a successive transfer was not certain (Korst and Velthuis, 1982).

When foragers enter the hive with nectar, they transfer it primarily to the food-storer task group (Seeley, 1989). It is possible that bees, like the food-storers, which disperse more throughout the colony than nurses, 
are of a greater importance for supplying the foragers with proteinaceous food than younger nurse bees. There is some preliminary support for this in results from laboratory experiments (Hrassnigg and Crailsheim, 1996). Dreischer (1956) supposed that foragers obtain jelly from food storers in exchange for nectar. We think that they depend on jelly, as a protein source, as though they were seen in pollen cells. As discussed above we only saw them in pollen cells but could not check consumption. Furthermore Crailsheim et al (1992) showed that foragers had very few pollen in their midguts and Moritz and Crailsheim (1987) and Szolderits and Crailsheim (1993) that their ability to digest it is limited.

The facts that even nurses that have high contents of pollen in their intestines (Crailsheim et al, 1992) were very seldom observed to eat pollen (1.25 times per day, calculated from our daily observation period of about $3 \mathrm{~h}$ during day and $3 \mathrm{~h}$ during night) and that the duration of this activity was very long (fig 4b), indicate that bees take on a large load with one feed. These findings of low numbers of pollen feedings per day are consistent with the observations of Lorenz and Crailsheim (1994) that pollen movement to the end of the midgut takes about half a day.

\section{CONCLUSIONS}

The two task groups, nurses and foragers, exhibit different day and night rhythms. For compelling reasons (eg, light, darkness) foragers show a very rhythmic behaviour, expressed primarily in flight activity. In addition to this, however, we have shown that in other activities and in their location inside the hive they depend on time of the day. Food collection during the day, a very energy-consuming task which limits lifespan (Neukirch, 1982), is followed by resting during the night. Nurses are influenced by the time of the day only in their effort to donate food by trophallaxis (Crailsheim, 1992), an activity in which at least one more rhythmic task group (foragers) is involved. In our observations their primary duty, the brood care, was not influenced by daytime.

\section{ACKNOWLEDGMENTS}

For help with the exhausting observations, especially during the night, we gratefully acknowledge D Riederer, A Delago, T Hötzl, U Riessberger and $M$ Rubinigg. We thank $S$ Camazine and $D$ Moore for intense discussion of the manuscript and $E$ Lamont for linguistic corrections. This project was supported by the Austrian Science Foundation.

\section{Résumé - Différences de comportement} entre butineuses et nourrices d'Apis mellifera le jour et la nuit. Des ouvrières s'occupant du couvain (nourrices ; définies par leur âge : 7 à 12 jours) et des butineuses (définies par leur comportement) ont été observées durant 1 heure et demie à midi et 1 heure et demie à minuit la nuit suivante. L'activité des nourrices (soin au couvain, patrouillage, travail de la cire, etc) et leurs phases d'inactivité étaient réparties de façon sensiblement uniforme entre le jour et le nuit (fig 2). Elles passaient environ la moitié du temps d'observation (53-60 \%) près du nid à couvain (fig 1). En revanche, les butineuses étaient nettement plus actives le jour que la nuit et au total plus actives le jour que les nourrices (fig 2). Elles passaient la majeure partie de leur temps en dehors du nid à couvain et effectuaient régulièrement des vols de butinage dans la journée (fig 1). La nuit elles se tenaient généralement dans la partie basse de la ruche, en dehors du nid à couvain. Les échanges trophallactiques des butineuses avaient lieu beaucoup plus souvent le jour que la nuit; elles étaient aussi plus souvent nourries (receveuses) que les nourrices (fig 3). Bien 
qu'on n'ait que rarement trouvé des butineuses près du nid à couvain, il semble probable qu'il y ait des échanges de nourriture entre les deux groupes du fait de la présence régulière des nourrices hors du nid à couvain. Les nourrices visitaient les cellules à pollen toute la journée et régulièrement la nuit, en moyenne 1,25 fois environ en 24 heures. On n'a jamais observé de butineuses se nourrissant elles-mêmes dans les cellules à miel. De même, la visite des cellules à pollen a été rarement obervée $(0,87$ fois en 24 heures) (fig 4). II ressort de ces observations que l'alimentation des butineuses a lieu très souvent par trophallaxie avec les abeilles d'intérieur.

\section{comportement social / polyėthisme / tro- phallaxie / jour-nuit}

\section{Zusammenfassung - Verhaltensunter- schiede von Sammlerinnen und Ammen- bienen (Apis mellifera carnica Pollm) während Tag und Nacht. Brutpflegende} Honigbienen (Ammen; definiert nach ihrem Alter von 7-12 Tagen) und Sammelbienen (definiert durch ihr Verhalten) wurden 1.5 Stunden lang zur Mittagszeit und in der folgenden Nacht ebenso lange um Mitternacht beobachtet. Die Aktivität der Ammen (Brutpflege, Patrouillieren, Wachsmanipulation, etc) und ihre Phasen der Inaktivität war annähernd gleichmäßig auf Tag und Nacht verteilt (Abb 2). Etwa die Hälfte der Beobachtungszeit (53-60\%) verbrachten sie im Brutnestbereich (Abb 1). Die Sammlerinnen hingegen waren bei Tag deutlich aktiver als bei Nacht und bei Tag insgesamt aktiver als die Ammen (Abb 2). Sie verbrachten die meiste Zeit außerhalb des Brutnestes und waren am Tag häufig auf Sammelflügen (Abb 1). In den Nachtstunden hielten sie sich vorwiegend im unteren Stockbereich, außerhalb des Brutnestes auf. Trophallaktische Interaktionen der Sammlerinnen fanden viel häufiger am Tag statt als in der Nacht, auch wurden sie häufiger gefüttert als die Ammen (Abb 3). Obwohl die Sammlerinnen nur selten im Brutnestbereich angetroffen wurden, läßt die regelmäßige Präsenz der Ammen außerhalb des Brutnestes (40-47\% der Beobachtungszeit) einen Futteraustausch zwischen diesen zwei Gruppen als wahrscheinlich erscheinen. Die Ammen besuchten Pollenzellen, tagsüber und nachts gleichmäßig, im Mittel etwa 1.25 mal in $24 \mathrm{~h}$. Es wurde nie beobachtet, daß sich Sammlerinnen selbst mit Futter aus Honigzellen versorgten. Auch der Besuch von Pollenzellen wurde selten beobachtet (0.87 mal in 24 h) (Abb 4). Man kann daher davon ausgehen, daß die Futterversorgung von Sammelbienen sehr häufig durch Trophallaxis mit Stockbienen geschieht.

\section{Verhalten / Arbeitsteilung / Trophallaxis / Tag-Nacht}

\section{REFERENCES}

Blom J (1993) Division of labour in honeybees: a revision. Proc Exp App/ Entomo/4, 91-96

Camazine $S$ (1993) The regulation of pollen foraging by honey bees: how foragers assess the colony's need for pollen. Behav Ecol Sociobio/ 32, 265-272

Crailsheim K (1991) Interadult feeding of jelly in honeybee (Apis mellifera L) colonies. J Comp Physiol B $161,55-60$

Crailsheim K (1992) The flow of jelly within a honeybee colony. J Comp Physiol B 162, 681-689

Crailsheim K, Schneider LHW, Hrassnigg N, Bühlmann G, Brosch U, Gmeinbauer R, Schöffmann B (1992) Pollen consumption and utilization in worker honeybees (Apis mellifera carnica): dependence on individual age and function. I Insect Physiol 38, 409419

Corbet SA, Fussel M, Ake R, Fraser A, Gunson C, Savage A, Smith K (1993) Temperature and the pollinating activity of social bees. Ecol Entomol 18, 17-30

Dreischer H (1956) Untersuchungen über die Arbeitstätigkeit und Drüsenentwicklung altersbestimmter Bienen im weisellosen Volk. Zool Jahrb 66, Abt Phys, 429-472

Free JB (1957) The transmission of food between worker honeybees. Br J Anim Behav 5, 41-47

von Frisch K (1965) Tanzsprache und Orientierung der Bienen. Springer, Berlin 
Frisch B, Aschoff $J$ (1987) Circadian rhythms in honeybees: entrainment by feeding cycles. Physiol Entomol 12, 41-49

Heinrich B (1979) Thermoregulation of African and European honeybees during foraging, attack, and hive exits and returns. J Exp Bio/ 80, 217-229

Hrassnigg N, Crailsheim K (1996) Trophallaxis of proteinaceous jelly in middle-aged honey bees. Apidologie 27, 311-312

Kaiser W (1988) Busy bees need rest, too. J Comp Physiol A 163, 565-584

Kaiser W (1995) Rest at night in some solitary bees - a comparison with the sleep-like state of honey bees. Apidologie 26, 213-230

Kaiser W, Steiner-Kaiser J (1988) Behavioural and physiological changes occurring during sleep in the honey bee. In: Sleep '86, (WP Koella, F Obál, H Schulz, P Visser, eds), Gustav Fischer, Stuttgart, 157-159

Korst PJAM , Velthuis HHW (1982) The nature of trophallaxis in honeybees. Insectes Soc 29, 209-221

Lindauer M (1952) Ein Beitrag zur Frage der Arbeitsteilung im Bienenstaat. $Z$ verg/ Physio/ 34, 299-345.

Lorenz W, Crailsheim K (1994) Transport of solids in the gastrointestinal tract of honeybees (Apis mellifera L). Mitt Dtsch Ges Allg Angew Entomo/ 9, 313315

Moore D, Rankin MA (1993) Light and temperature entrainment of a locomotor rhythm in honeybees. Physiol Entomol 18, 271-278

Moore D, Siegfried D, Wilson R, Rankin MA (1989) The influence of time of day on the foraging behavior of the honeybee, Apis mellifera. J Biol Rhythms 4, 305325
Moritz B, Crailsheim K (1987) Physiology of protein digestion in the midgut of the honeybee (Apis mellifera L). J Insect Physiol 33, 923-931

Neukirch A (1982) Dependence of the life span of the honeybee (Apis mellifica) upon flight performance and energy consumption. J Comp Physiol B, 146, 35-40

Rösch GA (1925) Untersuchungen über die Arbeitsteilung im Bienenstaat. I. Teil: Die Tätigkeiten im normalen Bienenstaate und ihre Beziehungen zum Alter der Arbeitsbienen. $Z$ vergl Physiol 2, 571-631

Rösch GA (1930) Untersuchungen über die Arbeitsteilung im Bienenstaat. 2. Teil: Die Tätigkeiten der Arbeitsbienen unter experimentell veränderten Bedingungen. Z Vergl Physiol 12, 1-70

Sauer S, Kaiser W (1995) Pollen foragers of the honey bee (Apis mellifera carnica $L$ ) rest in the hive at night. In: Learning and Memory. Proc 23rd (II) Göttingen Neurobiology Conference (N Elsner, R Menzel, eds) Thieme, Stuttgart, Germany, 253

Seeley TD (1982) Adaptive significance of the age polyethism schedule in honeybee colonies. Behav Ecol Sociobiol 11, 287-293

Seeley TD (1989) Social foraging in honey bees: how nectar foragers assess their colony's nutritional status. Behav Ecol Sociobiol 24, 181-199

Stabentheiner A, Kovac H, Hagmüller K (1995) Thermal behavior of round and wagtail dancing honeybees. J Comp Physiol B 165, 433-444

Szolderits MJ, Crailsheim K (1993) A comparison of pollen consumption and digestion in honeybee (Apis mellifera carnica) drones and workers. J insect Physio/ $39,877-881$ 